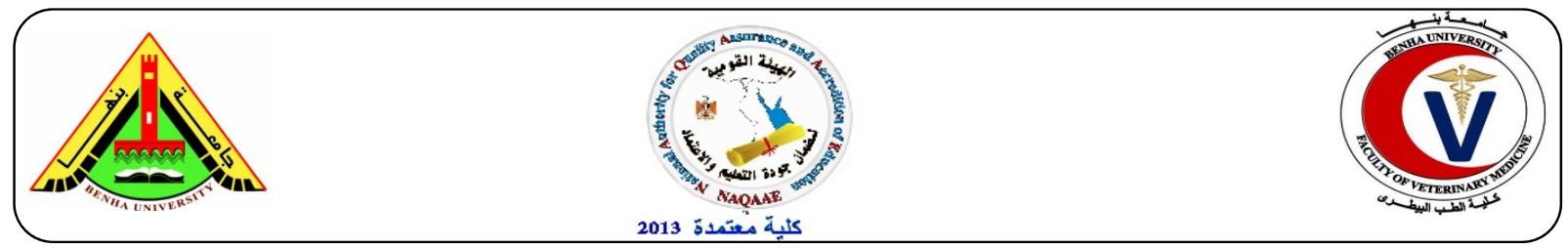

\title{
Staphylococcal contamination of cattle carcasses with particular reference to Staph. aureus enterotoxins.
}

\author{
Saad, M. S. ${ }^{1}$, Hassan, M. A. ${ }^{1}$, Abou El-Roos-Nahla, A. ${ }^{2}$ and Gaafar, M. H. ${ }^{2}$ \\ ${ }^{1}$ Department of food Hygiene, Fac. Vet. Med, Benha University, ${ }^{2}$ Food Hygiene Dept., Animal Health Research Institute \\ Shebin El- Kom branch.
}

\section{A B S T R A C T}

A total of one hundred random swab samples were collected from the cattle carcasses slaughtered at four different abattoirs located in Menufia governorate namely A, B, C and D (25 of each). The sampling site was randomly taken from each carcass inside the abattoir. Mean values of total Staphylococci count $\left(\mathrm{cfu} / \mathrm{cm}^{2}\right)$ of the tested cattle carcass swab samples obtained from abattoir A, B, C and D were $5.79 \times 10^{2} \pm 1.14 \times 10^{2}, 1.01 \times 10^{3} \pm 0.37 \times 10^{3}, 4.58 \times 10^{3} \pm 0.92 \times 10^{3}$ and $6.94 \times 10^{3} \pm 1.21 \times 10^{3}$, respectively. Isolates serotypes were Staph. Aureus (12\%), Staph. Epidermidis (4\%), Staph. Intermedius (0\%), Staph. Saprophyticus (0\%), Staph. Capitis (0\%) and Micrococcus spps (4\%) in abattoir A. While the fore mentioned serotypes were recorded in abattoir B in percentage of $(20 \%),(8 \%),(0 \%),(4 \%),(0 \%),(0 \%)$, respectively. On the other hand, the mentioned serotypes were recorded in abattoir $\mathrm{C}$ in percentage of $(24 \%),(0 \%),(0 \%),(4 \%),(0 \%)$, $(8 \%)$. Finally, in case of abattoir D the serotypes mentioned above found in percentage of $(40 \%),(8 \%),(4 \%),(0 \%),(4 \%)$, $(0 \%)$, respectively. Enterotoxin type A was produced by 2 strains of Staph. aureus at age of $13.33 \%$. While enterotoxin type B, D, A+C and A+D were produced by single strain of Staph. aureus for each at age of 6.67\%. On the other hand, enterotoxin type $\mathbf{C}$ is produced by 3 strains of Staph. aureus at age of $20 \%$. Finally, there were 8 strains of Staph. aureus was not capable of producing enterotoxin at age of $53.33 \%$.

Key words: cattle carcasses, abattoirs, Staphylococci count, Staph. aureus virulence genes, Enterotoxin.

(http://www.bvmj.bu.edu.eg)

(BVMJ-32(1): 94-98, 2017)

\section{INTRODUCTION}

Animal meat supplies human with good quality protein that could be polluted with several kinds of microorganisms resulting in numerous serious food borne diseases (Komba et al., 2012). Meat hygiene practice mainly established to inhibit disease conveying to human and supply him safe healthy meat for consumption particularly as meat deemed to be an important food and supplies human with high quality animal protein (Khamisse et al., 2012; Rivas-Cañedo et al., 2009). Animal flesh sold in butcher shops passes long series of steps as slaughtering and carriage; this meat may be exposed to microbial contamination at any of the steps. There are some leading factors participating in meat bacterial contamination as hygienic status of slaughterhouse and its surrounding environment (Gill et al., 2000). Staphylococcal foodborne intoxication occurs all over the world and caused by ingestion of already formed Staph. aureus enterotoxins in food causing clinical signs as vomition, diarrhea and even death in older people and children (Baumgartner et al., 2014).
So the current study aimed to detect Staphylococcal aureus contamination of cattle carcass in abattoirs and detect Staph. aureus different enterotoxin genes by using PCR that possess hazardous effects on human health consuming this meat.

\section{MATERIAL AND METHODS}

\subsection{Collection of samples}

One hundred random swab samples were collected from surfaces of cattle carcasses slaughtered at four different abattoirs located in Menufia governorate namely A, B, C and D (25 of each). The sampling site was randomly taken from each carcass inside the abattoir, each swab sample was kept in an isolated sterile plastic bag and kept in an ice box then transported to the research facility under entire aseptic conditions without impediment for bacteriological examination. The sterile cotton swab was drawn from screw capped plastic tube, wetted in rinsing fluid solution 
(buffered peptone water $0.1 \%$ ), then rolled over the limited area inside the template, rolled in one direction and perpendicular to this direction to represent all the examined area. Finally, the cotton swabs were aseptically retained into the rinsing fluid screw capped tubes containing ten milliliter buffered peptone water $(0.1 \%)$.

\subsection{Preparation of swabs (American Public Health Association "APHA", 2001):}

The collected swabs were mixed in $225 \mathrm{ml}$ of sterile buffered peptone water $(0.1 \%)$ to give $1 / 10$ dilution. $1 \mathrm{ml}$ from the original dilution was transferred with sterile pipette to another sterile test tube containing nine milliliter of buffered peptone water and mixed well to make the next dilution, from which further decimal serial dilutions were prepared. The prepared samples were subjected to the following examinations.

\subsection{Determination of total Staphylococci count (International commission of Microbiological Specification for Foods "ICMSF", 1996):}

Accurately, $0.1 \mathrm{ml}$ from each of previously prepared serial dilutions was spread over duplicated plates of Baired Parker agar using a sterile glass spreader. The inoculated and control plates were incubated at $37^{\circ} \mathrm{C}$ for forty eight hours. The developed colonies were enumerated and the total Staphylococci count $/ \mathrm{cm}^{2}$ was calculated. Also, the colonies were picked up and purified on nutrient agar slopes for Morphological examination and Biochemical identification.

\subsection{Isolation and identification of Staph. aureus.}

Colonies from Staphylococci count were picked up and purified on nutrient agar slopes for Morphological examination and Biochemical identification.

\subsection{Application of PCR}

\subsubsection{Primer sequences of Staph. aureus used for PCR system:}

Accurately, different enterotoxin primers as specific for demonstration of Staph. aureus enterotoxin virulence genes by PCR were used as shown in table 1

\subsubsection{DNA Extraction using QIA amp kit (Shah} (Shah et al., 2009):

\subsubsection{DNA amplification: Amplification reaction of Staph. aureus (Rall et al., 2008).}

\subsection{Statistical Analysis:}

The obtained results were statistically evaluated by application of Analysis of Variance (ANOVA) test according to Feldman et al. (2003).

\section{RESULTS.}

Results recorded in table (2) reported that total Staphylococci count $\left(\mathrm{cfu} / \mathrm{cm}^{2}\right)$ of the tested swab samples obtained from abattoir A ranged from $1.0 \times 10^{2}$ to $9.0 \times 10^{2}$ with an average of $5.79 \times 10^{2} \pm$ $1.14 \times 10^{2}$. And in case of abattoir B swab samples were, $1.0 \times 10^{2}$ to $4.0 \times 10^{3}$ with an average of $1.01 \times 10^{3} \pm 0.37 \times 10^{3}$. Also in abattoir $\mathrm{C}$ swab samples were, $6.5 \times 10^{3}$ to $1.0 \times 10^{4}$ with an average $4.58 \times 10^{3} \pm 0.92 \times 10^{3}$. And in case of abattoir D swab samples ranged from $4.0 \times 10^{2}$ to $3.0 \times 10^{4}$ with an average $6.94 \times 10^{3} \pm 1.21 \times 10^{3}$. Referring to Egyptian Organization for Standardization "EOS" (2008) and result recorded in table (3) show that meat obtained from abattoir A was $68 \%$, abattoir B was $48 \%$ accepted, meat obtained abattoir $\mathrm{C}$ is $40 \%$ accepted and meat obtained from abattoir D is $28 \%$ accepted.

As shown in table (4), the total isolates of Staph. aureus, Staph. epidermidis, Staph. intermedius, Staph. saprophyticus, Staph. capitis and Micrococcus spps. in abattoir A were (12\%), (4\%), $(0 \%),(0 \%),(0 \%),(4 \%)$, respectively. While the fore mentioned serotypes were recorded in abattoir $\mathrm{B}$ in age of $(20 \%),(8 \%),(0 \%),(4 \%),(0 \%),(0 \%)$, respectively. On the other hand, the mentioned serotypes were recorded in abattoir $\mathrm{C}$ in percentage of $(24 \%),(0 \%),(0 \%),(4 \%),(0 \%),(8 \%)$. Finally, in case of abattoir D the serotypes mentioned above found in age of $(40 \%),(8 \%),(4 \%),(0 \%),(4 \%)$, $(0 \%)$, respectively. From the results obtained by using Agarose gel electrophoresis of multiplex PCR of sea (120 bp), seb (478 bp), sec (257 bp) and sed (317 bp) enterotoxin genes for characterization of Staph. aureus present in table (5) and photograph (1) that revealing the different types of enterotoxins produced by Staph aureus were enterotoxin A is produced by 2 strains of Staph. aureus at percent of $13.33 \%$. While B, D, $\mathrm{A}+\mathrm{C}$ and $\mathrm{A}+\mathrm{D}$ were produced by single strain of Staph. aureus at $6.67 \%$ for each. On the other hand, enterotoxin C was produced by 3 strains of Staph. aureus at percent of $20 \%$. Finally, there were 8 strains of Staph aureus were not capable of producing enetrotoxin at age of $53.33 \%$. 
Table 1: Primer sequences of Staph. aureus used for PCR system.

\begin{tabular}{|c|c|c|c|}
\hline Target gene & Oligonucleotide sequence $\left(5^{\prime} \rightarrow 3^{\prime}\right)$ & Product size $(\mathrm{bp})$ & References \\
\hline sea $(\mathrm{F})$ & 5' TTGGAAACGGTTAAAACGAA'3 & \multirow{2}{*}{120} & \multirow{8}{*}{ Rall et al. (2008) } \\
\hline sea $(\mathrm{R})$ & 5' GAACCTTCCCATCAAAAACA ' 3 & & \\
\hline $\operatorname{seb}(\mathrm{F})$ & 5' TCGCATCAAACTGACAAACG '3 & \multirow{2}{*}{478} & \\
\hline $\operatorname{seb}(\mathrm{R})$ & 5' GCGGTACTCTATAAGTGCC '3 & & \\
\hline $\sec (\mathrm{F})$ & 5' GACATAAAAGCTAGGAATTT ' 3 & \multirow{2}{*}{257} & \\
\hline $\sec (\mathrm{R})$ & 5' AAATCGGATTAACATTATCC ' 3 & & \\
\hline sed $(\mathrm{F})$ & 5' CTAGTTTGGTAATATCTCCT '3 & \multirow[t]{2}{*}{317} & \\
\hline sed $(\mathrm{R})$ & 5' TAATGCTATATCTTATAGGG '3 & & \\
\hline
\end{tabular}

Table (2): Statistical analytical results of Staphylococci count $\left(\mathrm{cfu} / \mathrm{cm}^{2}\right)$ in the examined cattle carcass swab samples at the four tested Menufia abattoirs $(n=25)$.

\begin{tabular}{|c|c|c|c|c|c|}
\hline \multirow{2}{*}{ Abattoir } & \multicolumn{2}{|c|}{ +ve samples } & \multirow{2}{*}{ Min } & \multirow{2}{*}{ Max } & \multirow{2}{*}{ Mean \pm S.E } \\
\hline & No. & $\%$ & & & \\
\hline A & 13 & 52 & $1.0 \times 10^{2}$ & $9.0 \times 10^{2}$ & $5.79 \times 10^{2} \pm 1.14 \times 10^{2}$ \\
\hline B & 14 & 56 & $1.0 \times 10^{2}$ & $4.0 \times 10^{3}$ & $1.01 \times 10^{3} \pm 0.37 \times 10^{3}$ \\
\hline $\mathrm{C}$ & 17 & 68 & $1.0 \times 10^{2}$ & $1.0 \times 10^{4}$ & $4.58 \times 10^{3} \pm 0.92 \times 10^{3}$ \\
\hline $\mathrm{D}$ & 18 & 72 & $4.0 \times 10^{2}$ & $3.0 \times 10^{4}$ & $6.94 \times 10^{3} \pm 1.21 \times 10^{3 * *}$ \\
\hline
\end{tabular}

Table (3): Acceptability of the examined beef samples based on their Staphylococci count $\left(\mathrm{cfu} / \mathrm{cm}^{2}\right)(\mathrm{n}=25)$.

\begin{tabular}{cccccc}
\hline \multirow{2}{*}{ Locality } & \multirow{2}{*}{ APC $/ \mathrm{g} *$} & \multicolumn{2}{c}{ Accepted samples } & \multicolumn{2}{c}{ Unaccepted samples } \\
\cline { 3 - 6 } & & No. & $\%$ & No. & $\%$ \\
\hline A & 17 & 68 & 8 & 32 \\
B & $>10^{2}$ & 12 & 48 & 13 & 52 \\
C & 10 & 40 & 15 & 60 \\
D & & 7 & 28 & 18 & 72 \\
\hline Organization for Standardization "EOS" (2008). No 4334/2008 for fresh beef
\end{tabular}

Table (4) Incidence of Gram positive cocci isolated from the examined cattle carcass swab samples at the tested Menufia abattoirs $(n=25)$.

\begin{tabular}{lcccccccc}
\hline \multirow{2}{*}{ Gram + ve cocci } & \multicolumn{1}{c}{$\mathrm{A}$} & \multicolumn{1}{c}{ B } & \multicolumn{1}{c}{$\mathrm{C}$} & \multicolumn{2}{c}{$\mathrm{D}$} \\
& No. & $\%$ & No. & $\%$ & No. & $\%$ & No. & $\%$ \\
\hline Staphylococcus aureus & 3 & 12 & 5 & 20 & 6 & 24 & 10 & 40 \\
Staphylococcus epidermidis & 1 & 4 & 2 & 8 & - & - & 2 & 8 \\
Staphylococcus intermedius & - & - & - & - & - & - & 1 & 4 \\
Staphylococcus saprophyticus & - & - & 1 & 4 & 1 & 4 & - & - \\
Staphylococcus capitis & - & - & - & - & - & - & 1 & 4 \\
Micrococcus species & 1 & 4 & - & - & 2 & 8 & - & - \\
\hline
\end{tabular}

Table (5): Occurrence of entertotoxin genes of Staph. aureus strains isolated from the examined cattle carcass swab samples from the four Menufia abattoirs ( $\mathrm{n}=17$ strains).

\begin{tabular}{lcc}
\hline Staph. aureus enterotoxins & No. & $\%$ \\
\hline A & 2 & 13.33 \\
B & 1 & 6.67 \\
C & 3 & 20.00 \\
D & 1 & 6.67 \\
A + C & 1 & 6.67 \\
A+D & 1 & 6.67 \\
-ve & 8 & 53.33 \\
Total & 17 & 100 \\
\hline
\end{tabular}




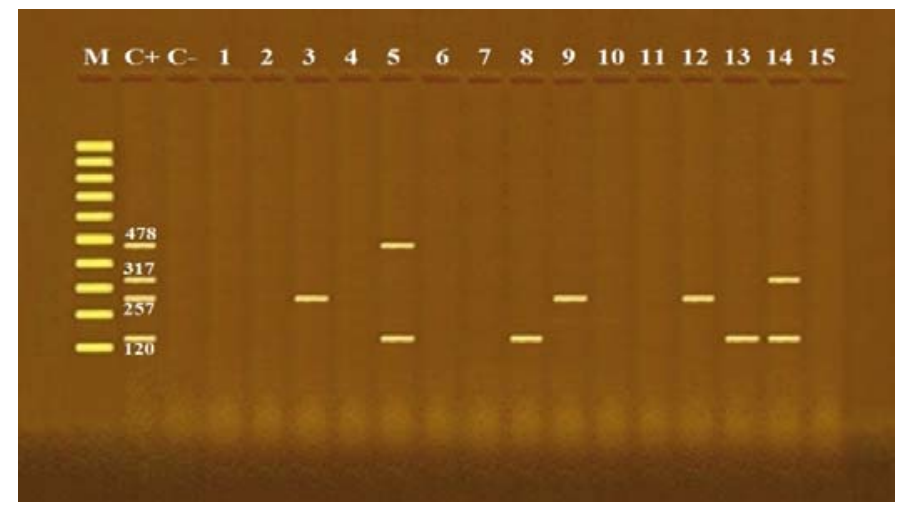

Photo (1): Agarose gel electrophoresis of multiplex PCR of sea. (120 bp), seb (478 bp), sec (257 bp) and sed (317 bp) enterotoxin genes for characterization of Staph. aureus. Lane M: 100 bp ladder as molecular size DNA marker. Lane C+: Control positive for sea, seb, sec and sed genes. Lane C-: Control negative. Lanes 3, 9 \& 12: Positive Staph. aureus strains for sec gene. Lanes 8 \& 13: Positive Staph. aureus strains for sea gene. Lane 5: Positive Staph. aureus strain for sea and seb genes. Lane 14: Positive Staph. aureus strain for sea and sed genes. Lanes 1, 2, 4, 6, 7, 10, 11 \& 15: Negative Staph. aureus strains for enterotoxins.

\section{DISCUSSION}

Foodborne intoxication due to eating meat contaminated with Staph. aureus and their toxins is considered a very dangerous problem threatening many countries all over the world, the hygienic conditions and manufacture practices of meat produced from abattoirs could be judged by performing Staphylococci count (Potter, 2001). According to results of total Staphylococci count $\left(\mathrm{cfu} / \mathrm{cm}^{2}\right)$ of the tested swab samples obtained from the four abattoirs we noticed that our results come in accordance with those reported by Magdy (1995); Salama (2013) and Bogere and Baluka (2014). While, higher results were obtained by Hejazi (2013) Ibrahim et al. (2013); Zaqzouq (2013) and Elshafay (2014). Furthermore, lower Staphylococci count in cattle swab samples were obtained by Darweesh (2004).

Carcass contaminated with Staph. aureus can be occurred during de - skinning and evisceration of carcass in abattoir and also can be contaminated by dirty equipment and workers unclean and wounded hands (Lasta et al., 1992). We found that the percentage of isolated Staph. aureus strains agreed with those reported by Abdallah et al. ( 2009b); Elshafay (2014); Haileselassie et al. (2013); Magdy (1995) and Adwan et al. (2015). While lower results were obtained by Adugna (2014); Ahmed et al. (2015) and Mathew et al. (2016).

From the results obtained by using Agarose gel electrophoresis of multiplex PCR of sea (120 bp), seb (478 bp), sec (257 bp) and sed (317 bp) enterotoxin genes for characterization of Staph. aureus present in table (5) and photograph (1) that revealing the different types of enterotoxins produced by Staph aureus. We found that enterotoxin A is produced by 2 strains of Staph. aureus at percent of $13.33 \%$. While enterotoxin B, $\mathrm{D}, \mathrm{A}+\mathrm{C}$ and $\mathrm{A}+\mathrm{D}$ were produced by single strain of Staph. aureus for each at percent of $6.67 \%$. On the other hand, enterotoxin $\mathrm{C}$ is produced by 3 strains of Staph. aureus at percent of $20 \%$. Finally, there were 8 strains of Staph aureus were not capable of producing enetrotoxin at percent of $53.33 \%$.

Staph. aureus contain numerous virulence factors including leukocidins, toxic shock syndrome toxin-1 (TSST-1), exfoliative toxins and staphylococcal enterotoxins (SEs). Staphylococcal enterotoxins (SEs) cause Staphylococcal food intoxication, they classified into SEA to SEE and $S E G$ to SEIU recently recorded (Fueyo et al., 2005).

\section{REFERENCES}

Abdallah, M.A., Suliman, S.E., Ahmed, D.E., Bakhiet, A.O., 2009b. Estimation of bacterial contamination of indigenous bovine carcasses in Khartoum (Sudan). Afri. J. Microbio. Res. 3, 882-886.

Adugna, F. 2014. Sudies on the prevalence, antibiogram, assessment of risk factors and public health significance of Staph. aureus in beef and environment at Addis AbabaM.Sc.

Adwan, G.M., Alqarem, B.R., Adwan, K.M., 2015. Prevalence of foodborne pathogens in meat samples in Palestine. Inter. Food Res. J. 22, 1806-1812.

Ahmed, A., Sabiel, Y., Fadolelgaleel, H., 2015. Bacterial contamination of beef carcasses in 
slaughter houses Khartoum State, Sudan.

Sudan J. of Sci. and Technol. 16, 9-14.

American Public Health Association "APHA", 2001. Compendium of methods for microbiological examination of foods. $4^{\text {th }}$ Edition 365-366-800. $1^{\text {st }}, \mathrm{NW}$ Washington DC 2000 1-3710.

Baumgartner, A., Niederhauser, I., Johler, S., 2014. Virulence and Resistance Gene Profiles of Staph. aureus Strains Isolated from Readyto-Eat Foods. J. Food Protect. 7, 1232-1236.

Bogere, P., Baluka, S., 2014. Microbiological Quality of Meat at the Abattoir and Butchery Levels in Kampala City, Uganda. Internet J. of Food Safety 16, 29-35.

Darweesh, M. 2004. Microbiological Picture of Retailed Meat in Menofiya Governorate. M.V.Sc., Alex. Univ.

Elshafay, M. 2014. Food safety of cattle meat and offal at abattoir level M.V.Sc., Benha Uni.

Feldman, D., Ganon, J., Haffman, R., Simpson, J., 2003. The solution for data analysis and presentation graphics, Abacus. Lancripts, Inc., Berkeley, USA.

Fueyo, J., Mendoza, M.C., Rodicio, M.R., Muniz, J., Alvarez, M.A., Martin, M.C., 2005. Cytotoxin and pyrogenic toxin superantigen gene profiles of Staph. aureus associated with subclinical mastitis in dairy cows and relationships with macrorestriction genomic profiles. J. Clin. Microbiol. 43, 1278- 1284.

Gill, C.O., Bryant, J., Brereton, D.A., 2000. Microbiological conditions of sheep carcasses from conventional or inverted dressing processes. J Food Prot 63, 12911294.

Haileselassie, M., Taddele, H., Adhana, K., Kalayou, S., 2013. Food safety knowledge and practices of abattoir and butchery shops and the microbial profile of meat in Mekelle City, Ethiopia. Asian Pac. J. Trop. Biomed. 3, 407-412.

Hejazi, M. 2013. Microbial changes in cattle carcasses stored at chilling conditionM.V.Sc.

Ibrahim, H., Amin, R., Saleh, O., El Shafay, M.S., 2013. Quality of beef and edible offal at abattoir level. Benha Vet. Med. J. 25, 254263.

International commission of Microbiological Specification for Foods "ICMSF", 1996. Microorganisms in Food. Their Significance and methods of enumeration. $3^{\text {rd }}$ Ed. Univ. of Toronto, Canada.

Khamisse, E., Firmesse, O., Christieans, S., Chassaing, D., Carpentier, B., 2012. Impact of cleaning and disinfection on the nonculturable and culturable bacterial loads of food-contact surfaces at a beef processing plant. Int. J. Food Microbiol. 158, 163-168.

Komba, E., Komba, E.V., Mkupasi, E.M., Mbyuzi, A.O., Mshamu, S., Luwumba, D., Busagwe, Z., Mzula, A., 2012. Sanitary practices and occurrence of zoonotic conditions in cattle at slaughter in Morogoro Municipality, Tanzania: implications for public health. Tanzania J. of Health Res. 14, 1-12.

Lasta, L.A., Radriguez, R., Zanelli, M., Morgaria, A., 1992. Bacterial count from bovine carcasses as an indicator of hygiene at slaughtering places. A proposal for sampling. J. Food Prot. 55, 271-278.

Magdy, A.W. 1995. Surface contamination of carcasses in modern and traditional abattoirM.V.Sc.

Mathew, B., Nanu, E., Sunil, B., 2016. Isolation of bacteria of public health significance from market beef. Int. J. Adv. Res. Biol. Sci. 3, 160-164.

Potter, N.N., 2001. Food Science., The AVI Publishing Co. Inc. New York. .

Rall, V., Vieira, F., Rall, R., Vieitis, R., Fernandes, A., Candeias, J., Cardoso, K., Araujo, J., 2008. PCR detection of Staphylococcal enterotoxin genes in Staph. aureus strains isolated from raw and pasteurized milk. Vet. Microbiol. 132, 408-413.

Rivas-Cañedo, A., Nuñez, M., Fernández-García, E., 2009. Volatile compounds in Spanish dry-fermented sausage 'salchichón' subjected to high pressure processing. Effect of the packaging material. Meat Sci. 83, 620626.

Salama, E.A. 2013. Sanitary conditions of cattle and camel carcasses at Menofia Abattoirs. PhD, Benha Univ. .

Shah, D., Shringi, S., Besser, T., Call, D., 2009. Molecular detection of foodborne pathogens, Boca Raton:. CRC Press, In Liu, D. (Ed). Taylor \& Francis group, Florida, USA.

Zaqzouq, G. 2013. Microbiological Aspects of Fresh Cattle and Sheep Meat In ElBehiraM.V.Sc., Fac.Vet. Med. Alex. 